\title{
Diasporic Nationalism, Citizenship, and Post-War Reconstruction
}

\author{
Khatharya Um
}

\begin{abstract}
While ties between Cambodian diasporas and Cambodia have been significant and enduring over the decades of conflict, the political changes engendered by the internationally endorsed elections of 1993 have transformed the scope and characteristics of the transnational traffic. Shaped by complex ideological, class, gender, and generational dynamics, Cambodian diasporas' re-engagement with the ancestral homeland has since acquired a multidimensionality that extends beyond mere monetary remittance. Spanning both private and public spheres, from national to household levels, these transnational encounters necessarily dislodge the narrow analytic focus and assumptions that accompany much of the discourse of transnationalism, and interrogate critical issues of nationalism, citizenship, and belonging.
\end{abstract}

\section{Résumé}

Malgré l'importance et la solidité des liens entre la diaspora cambodgienne et le Cambodge au cours de décennies de conflit, les changements politiques engendrés par les élections avalisées de 1993 ont modifié la portée et les particularités de la circulation transnationale. Le réengagement de la diaspora à l'égard de la patrie, influencé par une dynamique complexe quant aux idéologies, aux classes, aux sexes et aux générations, a depuis acquis une dimension multiforme qui dépasse la simple allocation monétaire. Ces rencontres transnationales, englobant les sphères privées et publiques, du foyer à la nation, écartent les hypothèses et les points de vue analytiques fermés qui accompagnent souvent le discours sur le transnationalisme. Elles remettent également en question les notions critiques de nationalisme, de citoyenneté et d'appartenance.

\section{Introduction}

$\mathrm{D}$ espite the challenges posed by protracted conflict, compounding dislocations, and distance, Cambodians dispersed throughout various refugee camps, in third-country settlement, and in Cambodia have maintained strong ties that extend not only across time and geography but also across multiple dimensions of economic, social, and political engagement. From the late 1970s to the early 1990s, when contact was constrained by political impediments, difficult access to the border camps and the economic hardships that confront new refugees in their countries of resettlement, these translocal relationships were sustained essentially through letters and financial remittances. In some instances, these exchanges were conducted between the many nodes in diaspora; in others, they made their way by circuitous routes from asylum in the West to needy families languishing in liminal refugee camps. Until the repatriation of refugees from the Thai-Cambodia border in 1991, remittances from overseas Cambodian communities provided a critical economic buffer, especially for families in camps not recognized by the UN. They continued, through the late 1980s and early 1990s, albeit in an imperceptible trickle, largely through the community of international non-governmental organizations (NGOs) that emerged following the collapse of the Soviet Union and the termination of Soviet subsidies. Following the repatriation of refugees from the Thai border camps back to Cambodia in 1991, support from overseas Cambodian communities was especially important for returnee families with little or no access to land and other productive means.

While transnational relations have been enduring and significant during the two decades of virtual regime isolation in Cambodia, the political changes brought about by the internationally endorsed elections of 1993 transformed the scope and nuance of transnational traffic. Liberalization of state control over movement of people, capital, goods, and information both into and out of Cambodia fortified 
and diversified transnational connections. Shaped by differing political tendencies and by complex class, gender, and generational dynamics, Cambodian diasporas' re-engagement of the ancestral homeland has since acquired a multi-dimensionality that, heretofore, has not been possible. Many overseas Cambodians embarked on the political routes initially through transnational activism during the conflict period and subsequently through participation in the post-war coalition government. Many more solidify their transnational ties through family remittances and sponsorship of development projects and cultural activities in Cambodia. Some opt for long-distance involvement, others for actual return. The greater number go back and forth in the attempt to reconcile the fissures of dislocated lives, families, and communities.

The lived experiences of Cambodian diasporas, as they reflect historical, temporal, and spatial multiplexity, ${ }^{1}$ challenge the bounded concept of the community and the linear approach towards migration. Rather than the presumed directional finality in the exit from one context and assimilation into another, Cambodian transnational experiences underscore the circularity of movement and the multidimensionality of connections. They dislodge the analytic centrality placed on monetary remittances that pervades transnational studies, and bring into focus the diverse forms, nuances, and textures of transnational connections that are equally compelling. They also interrogate the uncritical idealism that accompanies much of the discourse of transnationalism. The process of reconnecting and return for Cambodian diasporas, as it is for many transnationals, has not been without tremendous challenges. Their irrefutable agency notwithstanding, diasporas are constrained in their ability to effectively intervene and participate in homeland developments by the larger political, social, and economic contexts in which they have to operate both in their originary place and in their new places of resettlement. In the nexus of local, national, and global exigencies, agency and subjectivity exist in constant dialectical juxtaposition.

\section{Homeland and Exilic Longing}

In a context where rupture and entanglement, loss and remembrance, coexist in accustomed tension, the notion of time and space must be spoken of in terms of memory and imagination, in what Edward Said referred to as that "endless temporal notion in which past, present, and future intertwine without any fixed centers." 2 Being a refugee, as Hans Wicker points out, "means being engaged in a kind of lifelong psychological balancing act." ${ }^{3}$ For forcibly displaced individuals, the "discontinuous state of being"4 reflects the inability to free themselves from the past. Thus, as Homi Bhabha points out, rather than speaking of locality in "some utopian sense of liberation or return", "the place to speak from was through those incommensurable contradictions within which people survive, are politically active and change."5 In fundamental aspects, it is in the context of this liminality that attachment to the "homeland" becomes most registered. The poignancy of longing is rooted fundamentally in the denied possibility of return for in the reconstruction of myth and memory; it is, as Said puts it, "fragmentation (that) makes it even more real." 6

Cambodian diasporic longing for the homeland, as such, must be understood in light of the historical trauma of war, revolution, exile, and rupture. In essence, the nature and extent of the disconnection accounts for the reconnection that is sought. For many Cambodians, the rupture created by the losses and sufferings under the Khmer Rouge, and in the case of refugee survivors by physical dislocation from the homeland, was compounded by the nature of the atrocities. Disappearances and mass graves are especially significant in a Buddhist country because they deprive surviving relatives of the ability to perform the necessary rituals to ensure the successful transmigration of the soul, hence of the essential closure to these tragic life experiences. In many instances, this engenders a psychical sense of "being stuck" not only for the soul of the departed but for the survivors as well. Moreover, the virtual autarky that shrouded the country from 1975 to 1979 kept fractured families imprisoned in the liminality of not knowing. For many refugees, this "unresolved business" is made even more acute by the circumstances of flight-abrupt, often secretive and always perilous, resulting in further separation and deaths. These experiences combined account for the inability of the survivors to move forth towards building a new life and a new history. Memories of the past and of all that had been left behind essentially deny them the luxury of focusing on what they do have in the present and what they could envision for the future. Above and beyond the politics, the economics, and all the other "loftier" motivations, return for many Cambodian diasporas is compelled by that simple, yet insistent, need just "to light an incense" in remembrance.

The collective guilt of survivor-refugees is exacerbated by the conditions of post-war Cambodia. The decimation of the educated class and the enormity of Cambodia's needs exert additional pressure on the surviving and newly emerging professional and middle classes overseas. As reflected by Dr. Pen Dareth, who traded his lucrative position in Holland for a return home, "the country has helped me a lot by sending me abroad on a scholarship, now it's payback time. My conscience would not allow me to remain in Europe because I must help rebuild my country." Among the 1.5 generation $^{8}$ of Cambodian-Americans, in 
particular, one of the frequently proffered reasons for wanting to engage in the process of national reconstruction is simply that "we had the opportunity (for education, for jobs ... ) which people in Cambodia did not have ... Without Cambodia, I wouldn't be who I am; I need to put something back."

For diasporic communities, however, the longing for the homeland is rooted not only in the context of displacement but also in the experience of exile, reflecting diasporas' own positions and relationships with the receiving society. Ethnicity, as Sorenson points out, is "a product of interaction, not isolation." ${ }^{10}$ In this sense, the post-resettlement experience of the refugees and their relationship with the host society incubate that longing for return. For many Cambodian refugees, resettlement in the US has not been without considerable challenge. With a disconcertingly high rate of welfare dependency and statistics of over 41 per cent of the population living below poverty line,${ }^{11}$ Cambodian-Americans are part of that "implosion of the Third World into the First."12 Among first-generation refugees, relatively few professionals were able to re-enter that sector of employment after their resettlement in the US. Many gravitated towards social services, partly because it was an area where they could apply their bilingual skills and administrative training. Though civil service may afford them stability and social status, many remain frustrated with the downward mobility and the un-/under-fulfillment of their life aspirations. For many refugees, encounters with racism in America further underscore the denial of belonging.

The prevailing sense of marginalization and insecurity in diaspora amplifies the siren call of the homeland. The need to confront and navigate around multiple hegemonic contexts points to transnational social fields as being "in part shaped by the migrants' perceptions that they must keep their options open."13 Being "obliged to live within a transnational space and to make a living by combining quite different forms of class experience," migrants have to "continuously translate the economic and social position gained in one political setting into political, social and economic capital in another,"14 and in so doing, they "become skilled exponents of a cultural bifocality that defies reduction to a singular order." 15 In this sense, dual citizenship, as with many features of transnationality, should be looked upon not simply and simplistically in terms of splintered loyalty but as a strategy for maximizing social and economic capital in the effort to enhance the personal and collective sense of security. In Cambodia's stringently stratified society, where family names, educational achievement, former status, and even age continue to be reservoirs of traditional legitimacy, returning elites, even those who are economically dispossessed, can find personal affirmation and a raison d'être that anonymity of life in the US has robbed them of. If nothing else, the association with America commands a certain social and political premium. Framing the discussion of involvement and repatriation as such highlights the elements of expediency and instrumentality that are often overshadowed by the discursive preoccupation with the nobler motivation for return.

\section{Diasporas and Transnational Political Remittance}

Addressing the need to emphasize both the subjectivity and agency embedded in the refugee experience, Richmond advocated looking at refugees not "as helpless victims of forces beyond their control but 'survivors' who create something out of their crisis." ${ }^{16}$ Despite forcible displacement and dispersed resettlement, refugee families and communities had mobilized to provide economic and political support for the homeland. Vietnam's occupation of Cambodia was a rallying cry for Cambodian diasporas. Coalescing under the umbrella of the government-in-exile (CGDK), exiled intellectual, political, and military elites came together, bound by little more than their shared desire for regime change in Cambodia, to form the initial core of oppositional leadership. At the grassroots, in places such as Long Beach, Lowell, and Chicago, it was a common sight to see Cambodian refugees, most with little education and little previous political awareness, gathering in community halls or at the local temples after long hours at their factory shifts for meetings with party representatives in search of political and financial support. Meager earnings from low-wage labour made their way into party coffers. Local noodle houses were always abuzz with political debates and exchanges of homeland news drawn from community newspapers that are dedicated largely to political developments in Cambodia, with only a peppering of local news. Rural Cambodians, awakened from their pre-political state by the mass victimization of Khmer Rouge draconian policies, have come to recognize the direct relevance of politics to their welfare. Constituting the majority of the refugee population, these peasant-nationalists provided critical support for the diasporan political cause. The resistance movement, coordinated and supported largely from outside Cambodia, was one of the principal catalysts compelling the negotiated settlements that officially marked the end of the Third Indochina War.

Following the internationally brokered peace settlement, Cambodian-Americans advocated for and won the right to run for office and vote in the elections. As a result of political pressure from Cambodian-Americans and their international supporters, voting stations were set up at the UN headquarter in New York while eight political parties led by 
Cambodian-Americans participated in the 1994 elections. Over the last decade, returning Cambodian-Americans have held prominent positions in government and non-government sectors while many in diaspora continue to serve as critical links in the transnational networks committed to bringing about systemic change, some through advocacy and others, like the Cambodian Freedom Fighters, through more militant means.

\section{Community Organizations and Transnational Activism}

Where traditional leadership is dislocated and dispersed and the community fractionalized along multiple dimensions, organizations provide both the structure and the ideology for regroupment and involvement. In fundamental ways, community-based associations provide the space for affirming and expressing cultural and ethnic identity as well as the structure for channeling this expression into actions. ${ }^{17}$ For politically displaced diasporas for whom politics constitute a diacritical marker of their communal identity, the social and political domains are inseparable. As it was with the Korean and Sikh communities in America, communitybased institutions provide Cambodian-Americans a forum not only for the affirmation of religious and cultural identities but also for political activism. They serve as the institutional facilitators for local mobilization, providing venues for receiving representatives of the government-in-exile, channeling strategic access to a dispersed community, and acting as structural links among overseas Cambodian communities and between diasporas and the home country.

Given the bifocality of diasporic consciousness, participation in community programs thus enables diasporas to "live out the tension embedded in the 'experiences of separation and entanglement', of living here and remembering/desiring another place." 18

The self-perception of Cambodian diasporas as critical interlocutors of the country's political fate facilitates the merging of domestic and homeland agendas. Many community events reflect social and political concerns centred both in the US and in Cambodia, providing the leadership in diaspora with the means and opportunities to conduct homeland political work, in tandem with the fulfillment of their social service mandate. It is not unusual, therefore, to find event programs listing panels on Cambodian-American youth and educational issues alongside presentations on international border negotiations and democracy building in Cambodia. In the 1990s, the umbrella organization for Cambodian-American mutual assistance agencies, the Cambodian Network Council, would typically set aside each of the two days of the national convention for domestic and homeland issues respectively. In its present incarna- tion, the organization has added a "border committee," one charged with addressing Cambodia's frontier disputes, to its standing committee structure.

Organization, as Samuel Huntington argues, "is the road to political power," and that power can be leveraged both in diaspora and upon return to the ancestral homeland. In providing a forum for the articulation and reaffirmation of culture and ethnic identity, these organizations perpetuate a context where traditional norms regarding social status, leadership, authority, and relations of obligation are validated and reinforced. In this process, they provide the institutional base for the cultivation of patron-client networks and other forms of social capital that can be extended into the political arena in Cambodia, where personal loyalty remains a principal asset. Those with established power bases overseas can thus convert these political assets into access and influence in Cambodia. It is significant that, of the Cambodian-Americans who returned to hold important positions in Cambodia in both government and nongovernmental arenas, many emerged from the cadre of social service providers and from the leadership of community-based organizations in the US.

\section{Formal Economic Ties}

While homeland politics is a central preoccupation of Cambodian diasporas, it is also true that active (as opposed to supportive), high-level participation in the political process, be it in Cambodia or in diaspora, and long-term repatriation have been the privilege of the few. Even with the determination and desire to re-engage, many overseas Cambodians are unable to undertake long-term relocation because of economic constraints such as home mortgages, college tuition, and other family obligations. Moreover, access to positions and real money-making opportunities require not only economic but political capital, which many refugees do not have. These constraints, in effect, may reinforce transnational mobility as they necessitate constant movement back and forth.

For most Cambodian families, transnational ties are forged and maintained largely through non-political venues. For overseas Cambodians with business acumen and means, economic liberalization and the magnitude of the country's post-war needs make it possible to capitalize upon the comparative advantages that they possess - cultural and language competency, family and professional connections, as well as expertise and connections garnered in the West - to assume important roles as investors, entrepreneurs, and critical intermediaries for firms seeking to do business in Cambodia. Cambodian-American owned companies, travel agencies with multinational branch offices, hotels and motels, restaurants, fast-food eateries, and even 
a private college have mushroomed since the political opening in 1993. While the incipient nature of the legal and business infrastructure and lack of systemic transparency in Cambodia continue to deter many potential investors, they also provide an environment in which more opaque business undertakings do thrive. Though relatively little capacity building and technology transfer have taken place, these intermediations have yielded benefits for Cambodia. As a Delcom representative points out, access brokered through the Cambodian-American connection brings in critical resources to the country: "Delcom has brought in a lot of money and expertise by building the first power plant. We ensure there is transfer of skills and technology to Cambodia. We have also created jobs for hundreds of local workers." 19

In spite of opportunities and interest, there are factors that limit entrepreneurial activities. The destruction of strategic human resources under the Khmer Rouge further eroded the weak entrepreneurial base left in place by Cambodia's colonial experience, accounting for the limitation of social and economic capital within the diasporic community. As a result, most of the business enterprises, such as doughnut franchises, are linked to the small community of Sino-Cambodians who historically constitute the commercial backbone of Cambodia's economy. Following the political opening of Cambodia, these are the individuals who are well-positioned to capitalize on the emerging opportunities.

\section{Non-Formal Transnational Economic Engagement}

Though Cambodia has since made a transition from rehabilitation to slow development and the enthusiasm of the international business community has sobered over the years, overseas Cambodians continue to play significant roles in the country's economic development, particularly through non-formal avenues. As people travel back and forth, goods are brought in and sold in both market arenas, at the very least as a way of deferring the cost of travel. Traditional handicrafts, gems, textiles, and ethnic foods, items much desired in diaspora, now stock the shelves of ethnic grocery stores in America's inner cities while medicines, second-hand goods, and luxury items of the West find their way through the labyrinth of family-based economies in Cambodia. The dynamics observed in the Dominican immigrant community are mirrored in the Cambodian transnational experience: "to the untrained eye, these travelers may appear as common migrants visiting and bearing gifts for their relatives back home, when they are actually engaged in trade." 20 In a refugee community of high English-language illiteracy, particularly among the older popu- lation, "trip facilitators" find a lucrative niche as travel escorts and facilitators of home visits. This was particularly true in the earlier years when travel to Cambodia was much more complicated than it is presently. In a country with weak banking infrastructure, carriers with service charges ranging from 10 to 25 per cent, depending upon the accessibility of the destination, continue to provide the principal means of capital remittance. In a country of high illiteracy and little trust, video technology provides instant confirmation of the transaction. Not uncommonly, individuals are simultaneously engaged in multiple "informal" activities. Travel, for instance, may be financed through "service fees," while expenses can be deferred, and profit made, through the sale of goods brought into and out of both Cambodia and the US.

\section{Transnational Cultural Projects}

In light of the dislocations that surviving refugees experience, the struggle to "make whole again" begins with the attempt to thread some continuity into life in exile. Community events are thus replete with cultural activities that not only affirm their cultural identity as Cambodians in America but also bridge the present with the interrupted past. Religious ceremonies are aimed not only at the wellbeing of the refugee communities in America but also destined for those left behind in Cambodia. Conducted in makeshift temples or in rented high school auditoriums, ceremonies such as Pchum Ben, the day of the ancestors, are marked as much by the sense of continuity as they are by the absence. Faded pictures and names scribbled on torn pages from school notebooks lie on the offering tables. For many refugees, young and old, these rites are no longer simply performative but are imbued with the rawness of irreparable loss. The genocidal experience intrudes in what, in the past, has been a largely ritualistic, cultural moment:

It always reminds me of my older sister who died from starvation in the Khmer Rouge regime ... It is believed that Pchum Ben is the time when the souls of the dead are set free from hell and the living relatives must start to make offerings in food and gifts of religious value to their dead ancestors or the spirits ... I always think that my sister soul always comes and rests with my family during the days of the festival. And, I still maintain the same feeling that she is still very hungry. And I want to give her rice to eat. ... ${ }^{21}$

With increased travel and communication between the homeland and diaspora, religious and cultural activities have acquired a transnational feature. Whereas previously activities such as the Pchum Ben are largely confined to the community in the US or in Cambodia, surviving families 
now remit money to Cambodia for the conduct of religious ceremonies and for exhumations and reburials from Khmer Rouge mass graves. As "community" comes to be defined transnationally, communal mobilization around religious activities such as the Krathen festival, dedicated to temple fundraising and other merit-making projects, necessarily extends across nation-state boundaries and geopolitical divides. Collectively, Khmer Buddhist communities, from Long Beach to Lowell to Philadelphia, have actively raised funds for religious projects in Cambodia, whereas previously these activities were confined to local communities in the US. The ability to organize and participate in the Krathen in Cambodia allows Cambodian-American elderly to reconcile, in however small measures, with the fact that they will have to live their final years in exile.

Beyond the religious arena, the desire for re/connection that had spurred sister-cities campaigns aiming to pair Phnom-Penh with Long Beach, California, and Sihanoukville with Seattle, Washington, also saw local expressions. Hometown associations and alumni groups have contributed to the construction and renovation of schools and clinics in their native communities. Under the leadership of Mr. Thavy Nhem, for instance, the Beng Trabek High School Alumni Association raised \$50,000 for the rehabilitation of their alma mater. ${ }^{22}$ Similarly, alumni of the pioneer Lycee Sisowath with their historical involvement in political activism in France now extend their mobilization to other diasporan communities and to non-political multinational projects.

As bridges that link and transcend temporal, geographical, and political distance, transnational activities allow diasporas to reconnect with homeland village communities and to feel a renewed sense of empowerment as active contributors to national reconstruction. Through these contributions and renewed ties, individuals and families also reap social status and insure their place in an established community. One Cambodian-American professional who funded the construction of a clinic in his family's natal province puts it as follows: "my family is from that area. It is a way of keeping the family name in that place." 23 The same spirit reverberates in Mexican-American transnational communalism, “. . . the Absent Ones, Always Present." ${ }^{24}$ After two decades of war and destruction, these construction projects stand as the "aesthetics of dislocation," 25 edifying the creative and regenerative impulses of a fractured and wounded community. Against the backdrop of political instability and endemic uncertainty, these structures, be they religious or secular, are venues for ascertaining a certain permanency of presence, of belonging, memorialized in defiance of temporality.
There is, additionally, an immeasurable sense of empowerment that comes with this transnational sponsorship. For a people weighed down by the loss of self-determination, the ability to undertake positive actions, to see that one's simple actions are bettering numerous lives, can be overwhelmingly gratifying. Given relative deprivation, even the economically marginalized in the US can become benefactors back in Cambodia. As one proud sponsor of a well-digging project in Takeo province pointed out, "At night I go to bed and think about people drinking my water, cooking food with it and bathing from the clean water of my well. Where else can one get that level of satisfaction for a mere \$200!"26 Transposed onto an alternate arena, dispossessed and marginalized refugees in America can and do become power wielders; they are not simply impoverished and subjugated minorities but individuals with knowledge and resources to impart, irrespective of socio-economic standing, gender, and age. In a country where 90 per cent of the population are Buddhists, and where the Buddhist wat stands at the social and cultural centre of every Khmer village community, temple renovation and construction are fundamental aspects of national reconstruction. For elderly refugees with limited education and economic means, participation in these transnational cultural activities thus enables them to assume a position of leadership, both in the diasporan community and in their natal community in Cambodia, and to be meaningfully engaged in the process of change, thereby validating their continued importance and relevance.

Along with the spiritual and psychical rationale for engagement, there is also a utilitarian imperative for the maintenance of transnational ties. In fundamental ways, these multi-faceted remittances can be read as practical investments. With concentration in low-wage, low-security employment sectors and high dependence on public assistance, the Cambodian American community remains plagued by economic vulnerability. In light of this continued marginalization, remittances can be viewed as strategic efforts to enhance economic security with accumulation of assets in Cambodia. Given the relative affordability of land and the porous tax collection system in Cambodia, the purchase of property in Cambodia is an investment that yields not only economic returns but also psychical benefits by making it possible for first-generation refugee, most of whom are of agrarian background, to dream of spending their golden years back in the ancestral country where they can enjoy a higher quality of life. ${ }^{27}$ In the same vein, providing monetary gifts and loans to families and investment in family enterprises is a way of buying into a future back in Cambodia. These strategies mirror those adopted earlier 
by Portuguese-American elderly in the years prior to the institution of social welfare programs in the US.

\section{Gender, Generation, and Transnationalism}

In addition to class, the ability of diasporas to re-engage the homeland and to undertake an actual return is also filtered through gender and generational prisms. In a country with an acute shortage of skilled human resources, returning Cambodians with their inherent comparative advantages can access opportunities not easily found in diaspora. Possession of a degree from an American institution, regardless of whether or not it is accredited, work experience in the West, and command of the English language are valued assets in Cambodia. With economic and political liberalization and the country's heavy dependence on foreign assistance and process, employment opportunities have proliferated, especially in the public and private sectors. Armed with Western training and education, newly minted college graduates with little or no experience can access positions of responsibility with governmental and non-governmental agencies at a level that elsewhere would not be possible. Some have been able to assume leadership roles that have been impossible to achieve in diaspora where community politics remain dominated by the older generation.

In the immediate aftermath of the peace settlement, optimism about diasporas' contributions to Cambodia's post-war reconstruction led to the creation of various programs to facilitate the transfer of skills. Along with the employment opportunity that accompanied the growing presence of international NGOs in Cambodia, these channels also provide important entrée for those desiring return and re-engagement outside the political arena. As a result, many Cambodian American youths are able to return to Cambodia through educational or international aid programs. Commonly referred to as the "Cambodian Peace Corps," the CANDO program, for instance, conceived and administered by a national Cambodian-American organization with USAID funding, brought back a number of young volunteers to work in Cambodia in the early 1990s. Younger-generation Cambodian-Americans also actively engaged in fundraising for various development projects in Cambodia. In the late 1990s, a transnational campaign to build a dormitory in Phnom-Penh for low-income students from the rural areas received much endorsement from the Cambodian-American community. Various student associations in California have been involved in establishing scholarship funds for needy students in Cambodia. Following the assassination of Oum Radsady, a respected adviser to Prince Ranaridh, overseas Cambodians created a scholarship program in his name. Other community and stu- dent-led initiatives include the remittance of funds by Cambodian students at Berkeley to an orphanage in northwestern Cambodia in 1998 and collection drives for books and equipment to be sent to educational institutions in Cambodia, as well as donations to help the reintegration of Cambodian-American deportees.

Cambodian-American women, still hindered by the embedded patriarchy of diasporic politics, also find a ready niche within the emerging leadership in Cambodia. Many have found that their experiences and leadership skills, largely acquired through participation in American social services or in community-based organizations, are needed in a post-war society where women accounted for over 50 per cent of the population and where gender issues remain pre-eminent national concerns. Many returning Cambodian-American women also feel that in a situation of persistent political volatility, their presence can serve as a stabilizing force. One social advocate who had returned to Cambodia since the early 1990s observed: "Women have a cooler nature so they are not quick to anger and don't aggravate a potentially explosive situation. They can also say things that a man would take personally if they were to come from another man." 28 Though the leadership skills and the experiences remitted through returning Cambodian women have been most impactful in non-governmental sectors, their presence has also been registered in national politics. One of the political parties in the 1998 elections was led by a Cambodian-American woman from northern California. In the last coalition government, two of the top positions in the newly reconfigured Ministry of Women's and Veterans' Affairs were held by returning Cambodian women, both from California. Their affiliation with opposing parties underscores the ideological pluralism of overseas Cambodians.

\section{The Role of Receiving State}

Evidence of sustained transnational ties and initial enthusiasm about the contributing roles of returning diasporas notwithstanding, post-war reality fell short of the expectations. The ability of diasporic communities to fully participate in homeland developments was thwarted by constraints that are internal to the community and external to them. Political instability, prevailing distrust, and lack of genuine interest in cultivating diasporas' potential contributions or in facilitating the transfer of skills and resources stand as significant impediments to sustained transnational involvement. In examining diasporas' engagement with the homeland, it is therefore important to take into account not only their desire for reconnection but also the opportunities that are presented to them to re-engage and their ability to capitalize upon them. Their agency notwithstanding, dias- 
poras are also fundamentally subjected to forces beyond their control. In critical ways, both the sending and the receiving regimes influence diasporan politics and shape the nature, scope, and depth of transnational linkages. For one, the state and condition of the host economy impacts upon the ability of people to remit resources and to travel back and forth. The welfare reforms of 1996 and the uncertainties that they engendered particularly among Cambodian elderly hampered transnational activities. With the majority of Cambodians in the US still without American citizenship, anxieties engendered by the 1996 immigration reforms also deterred the transnational flow.

Especially with regard to political activities, the ability of diasporic communities to effectively advocate for homeland causes depends to a large extent upon the receptivity and tolerance of the host polity, hence upon the alignment of the political agendas of the diasporic community with those of the host government. History has shown that exiles' political concerns can be advanced or deterred, depending upon the degree to which the host regime identifies with these causes, upon the nature and status of bilateral relationships between the two governments, and upon the position that the receiving regime adopts on critical issues such as democracy and human rights. Where diasporan politics contradict the national interests, their cause célèbre is often paralyzed by the political disregard of their adoptive governments as evidenced by the stillborn resistance politics of the Vietnamese-American community. In the context of the Cold War, the ideological commonality and overlapping policy agendas between Washington and the Cambodian non-communist groups in the 1980s and 1990s facilitated the lobbying and advocacy work of Cambodian diasporas. Washington's support of the non-communist Cambodian factions during the conflict period, crucial to the military and political campaigns of the government-inexile, contrasts markedly with the notable reserve a decade later with which the US government, now wedded to the "successful" implementation of the Cambodia Peace Plan, responded to the attack and suppression of pro-democracy forces in Cambodia.

\section{The Role of Sending State}

Sending, like receiving, states can do much to facilitate or impede transnational relations. Essentially, whether or not the social, economic, and political capital that émigrés may possess is fungible across transnational domains depends upon the receptiveness of the home regime. Through legislation and policies, governments can choose to include or deny possibilities and incentives for diasporic contributions, and in so doing define the parameters, terms, and nature of involvement. A regime's openness to diasporas can be in- ferred from its policy articulation that gives priority to political reconciliation and economic rationality over power consolidation and continued state control. The extent to which governments are willing and able to create mechanisms to facilitate capital remittance is an important gauge of their attitude about diasporic contributions. In the case of India, for instance, large government subsidies of nonresident Indian investment contributed to a significant repatriation of capital from overseas Indian communities. In contrast, the Cambodian government has been unsystematic in its solicitation of diasporic involvement. Its ability to strategically capitalize upon transnational remittance of capital and expertise has largely been undermined by prevailing distrust, weak and corrupt institutional and legal infrastructure, a governance system paralyzed by partisanship, and a state vision equally undercut by the same political impediments.

Conversely, wariness on the part of home regimes, on the other hand, can be deduced from legislative measures that seek to restrict, limit, and render ambiguous the role of overseas ethnic communities. Laws such as those regarding property ownership, citizenship, and associated rights define the possibilities for diasporas' political and economic participation. The contestation of dual citizenship, for instance, signals the Phnom-Penh regime's persisting regard of returning Cambodians as the "perpetual outsiders." In the same vein, lack of systemic transparency, poor legal infrastructure, persisting political volatility, and intrusion of politics in critical aspects of the society and economy deter genuine commitment to long-term investment; many of the economic initiatives remain "get-rich quick" schemes. That many returning Cambodian-Americans had to relive a replay of traumatic flight during the coup in July 1997 did little to restore diasporas' confidence.

While it can be argued that the dominating Cambodian People's Party may harbour distrust of diasporic communities and of transnational connections, it is also true that the Party, and particularly factions and individuals within it, profits from these connections. Distrust notwithstanding, elements in the Phnom-Penh regime do recognize the potential of overseas Cambodians to provide valuable links to public and private sectors outside of Cambodia, to tap into international and transnational resources and support given the connections and networks that they possess, and to be important advocates especially in their adopted countries. In the early years of political liberalization when the heretofore cloistered socialist government was feeling its way towards closer relations with the West, regime supporters within the Cambodian-American community were particularly instrumental in helping government officials navigate the labyrinth of the American political system. 
Over the years, Cambodian-Americans had helped garner political support from various US administrations on critical initiatives such as the extension of the Most Favoured Nation status to Cambodia. In the aftermath of the bloody coup in 1997, a team of politically savvy CambodianAmericans was redeployed back to the US to exercise damage control and to conduct aggressive public relations campaigns on behalf of the Cambodian government. A White Paper generated by the Cambodian People's Party (CPP) justifying the coup found its way into the Cambodian-American community through regime supporters, some of whom, ironically, were seeking temporary refuge back in the US in the face of renewed civil war. Ensconced in the safety of their American suburban homes, they eloquently argued for the necessity of state repression.

The Cambodian experience points to the importance of looking both at the state and at the diasporic community not as monolithic constructs but as comprising competing and conflicting interests. Additionally, in looking at regime responses, distinctions must also be made between initiatives that are pre-emptively undertaken by the state and those that are reactive to developments and dynamics beyond their control. While the communist faction in Phnom-Penh may try to curtail the role of overseas Cambodians, the reality remains that participation of Cambodian diasporas was an integral part of the negotiated settlement. In effect, while the communist-controlled government may be able to deter, shape, and influence the nature, level, and scope of transnational linkages, they cannot sever them without tremendous economic and political costs. This litmus test came in the wake of the 1997 coup that drove most of returning Cambodians back into exile, and threatened to unravel both the structure and the spirit of the power-sharing agreements. Signals conveyed to the Hun Sen regime in the form of frozen international assistance and diplomatic protestation compelled the communist faction to move away from its hardline position and to include the non-communist groups in the 1998 elections. Despite having consolidated their political and military power, the CPP was unable to divest itself of the power-sharing structure.

\section{The Role of International, Transnational, and Supranational Forces}

Just as the state emerges as an important variable in the analysis of transnationalism, so are international forces critical to the Cambodian transnational experience. Where the state is autocratic and civil society incipient, dissenting voices will have to find resonance through transnational connections. The strengthening of vertical and horizontal networks means that public accountability is no longer confined to the conventional boundaries of national communi- ties. Towards these ends, faxes and the Internet make communication relatively easy and almost instantaneous, and also infuse a poignant sense of immediacy to events that would otherwise be lost amidst the media deluge of international crises.

In the case of Cambodia, international monitoring, exercised through both governmental and non-governmental mechanisms, has been instrumental in safeguarding the role of diasporas in the nation's post-war political processes. Since the brokering of the peace settlement, international signatories have provided important intervention during critical periods of turmoil. Following the communist-led coup of 1997, international pressure exerted upon the Hun Sen regime made it possible for the non-communist political leadership to continue participation in the country's political processes. Though international stance has been compromised in various instances by realpolitik, the works of international NGOs, continuously advocating for systemic reform and accountability in critical areas such as environmental protection and human rights, help reinforce the protestations from Cambodian diasporas. While donor countries, heretofore, have been reluctant to attach conditionality to their assistance programs, the decision reached at the December 2004 donor meeting to insist upon measurable reform progress is a significant step towards greater accountability. Given the prevailing political climate in Cambodia, it would be difficult to assume that these pressures would be exerted simply by forces within the country or even by Cambodians alone.

\section{The Problematics of Return}

The intellectual optimism that is foregrounded in the discussion of transnationalism frequently deflects analytic attention from the more destabilizing impact of these transnational dynamics on social and cultural institutions and on interpersonal relations that are also present. In many respect, Cambodian transnational developments are relatively recent phenomena. Though linkages have been developed and maintained over the last two decades of diaspora, the deepening and diversification of the transnational connections have registered, in slow increments, only since 1989 and, dramatically, only since the elections of 1993.

Despite the recency of these developments, some disconcerting reverberations are already beginning to be felt. The inflated expectation of expertise and resource remittance from overseas communities did not account for the challenges of return and reintegration.

For the most part, national reconciliation in Cambodia has been symbolic, with structural integration largely masking the power asymmetry that still prevails within the coalition government. Despite the rhetoric, distrust of diasporas pre- 
vails. For younger-generation Cambodians, in search of a sense of belonging denied them by the racial politics of America, Cambodia represents communal acceptance and security that, in many instances, never materialize. For some, reconnection with the ancestral country allows for a movement away from internal confusion towards multi-faceted loyalties and a hyphenated sense of identity. For many, the anticipation of a seamless reconnection was marred by the cultural and ideological distancing that they encounter, poignantly conveyed through the ascription of the term anikachun - literally translated as "ethnic minority" - for overseas Cambodians. The sense of alienation that one volunteer experienced during her stay in Cambodia, feeling "that I am just observing but not participating," ${ }^{29}$ is also shared by a fellow returnee who commented that "it was like I was in my country but not my home." ${ }^{30}$ Disillusioned by present-day ills of Cambodian society, a young Cambodian-American professional reflected: "Cambodia is behind me now. I have to concentrate on building a life here in America."31 At least for this young Cambodian-American, return has lent itself to the final rupture.

The implications of return for both the community in diaspora and that in the originary context are also felt in other ways. Repatriation of talent divests the diasporan community of much-needed human capital. Given that leadership is largely drawn from the pool of communitybased organizations, there is institutional destabilization that results from the shortage of people to run programs and to provide community leadership, at a time when vulnerable communities are particularly impacted by changing socio-political and economic trends in the US. In various locales, such as Oakland and San Francisco with a combined population of about twelve thousand Cambodians, the departure of agency directors and community advocates in search of greater prospects in Cambodia left Cambodian refugee communities without the institutional support that had heretofore been provided by communitybased organizations. Whereas at the height of the refugee resettlement era, the Cambodian community in the US could count on the resources of some two hundred mutual assistance agencies, at present there are only around twenty viable organizations nationwide. As that generation of social service providers approaches retirement age and as the future of social service programs becomes even more precarious under the present political trends in America, it can be assumed that the repatriation of diasporic talent and leadership to Cambodia will increase. While this development may yield opportunities for a younger and more invigorated leadership to emerge, leadership transition has not always been smooth and effectual. American education and success in mainstream professional arenas do not nec- essarily translate into effective functioning in a community still comprised of first-generation refugees with limited ability to speak English. The younger generation of leadership that is now at the helm of many organizations frequently finds itself unable to negotiate the complex, multigenerational issues that beset the community. Until new leadership can be cultivated and legitimated in multiple political, cultural, and generational contexts, community advancement will continue to be undermined by organizational instability and the absence of effective leadership.

In addition to the adverse implications for community institutions, transnational developments also have a profound impact on family institution and relations. Though the full extent of the challenges remains to be systematically uncovered, evidences of change in kinship dynamics are already registering in various dimensions. Transnational familial relations have been destabilized by the added economic hardship, irreconcilable expectations, and asymmetrical power relations that remittance entails. Given the cultural emphasis on gift giving, return visits can be costly for diasporas already living on economic margins. For many, there is the added pressure to "live up" to the image of the successful migrant to which all-too-many respond by going into severe debt. Within the diasporic community, efforts to sustain transnational relations have paradoxically eroded the foundation of the nuclear family in America. For many refugee households, the demand of transnational obligations exerts tremendous pressure on marriages and on the household. This situation is further complicated when it involves distant but sole surviving relatives. Given that most of the returnees are male, an increasing number of Cambodian-American women are finding themselves becoming de facto heads of household, having to provide financial support not only for the family in the US but also for their self-repatriated spouses.

Moreover, the concept of "extended" families, in many instances, has acquired a transnational dimension, including in some cases multiple and simultaneous, formal and informal "marriages." The opportunity for finding a new and, in most cases, much younger and "more traditional" (often defined as more submissive) wife in Cambodia is capitalized on by returning Cambodian men with ever greater frequency. This recourse has presented itself as a way of countering the enhanced independence that Cambodian-American women are achieving through education and workforce participation, particularly outside the home, hence of reinforcing patriarchal dominance within the Cambodian-American community. Interestingly, this practice is not confined to the older generation but has also become increasingly appealing to the younger generation. The attractiveness of transnational marriage is also seen in 
the resurgence of the end-of the-century equivalent of the "picture bride," facilitated in this contemporaneous context through the Internet. Whereas one can argue that traditional marriages have always involved brokered arrangements of convenience and expediency, it is important to note that distance and migration divest this process of the mediating and protective social and normative mechanisms that governed the traditional system. The lure of a promised escape from poverty often obscures a harsher reality that awaits many of these young brides as they may find themselves entering into a polygamous situation, or left without the emotional and economic security that they seek. For their part, the men may find that these "visa marriages" do not yield the desired harmony, docility, and stability, as some of the women are quick to seek new options after having secured entry into the US.

Relational tension is also evident across the geographical divide. Though they may benefit from the economic support extended to them, relatives in Cambodia may also feel tremendous resentment towards what they perceive as condescension of their overseas benefactors. On their part, Cambodian-Americans are frequently offended by what they view as materialism and presumption of their kin at home. The resentment at being regarded merely as a financier is often compounded by the frustration about the seemingly limitless expectations of their kin-recipients: "We work hard in America; I don't have money for them to squander." 32 Younger Cambodian-Americans, perhaps less burdened by guilt than their elders, are most vociferous about what they regard as abuses of generosity: "The relatives in Cambodia are abusing the money we send them. They do not use the money as we intended. They use the money for eating out . . . for Seiko watches, expensive jeans." ${ }^{33}$ Adoption of the capitalistic emphasis on time and money has also contributed to changing norms governing relational obligation. Whereas relatives in Cambodia may continue to view these remittances as "gifts," extended without expectations or conditions, diasporas often regard these ties on different terms. One Cambodian-American woman pointed out that attaching conditionality to these remittances "like a contract, a business arrangement" is a way of helping the Cambodian people by educating them to new and "more efficient" ways of managing their affairs. ${ }^{34}$ Given the power asymmetry inherent in the relationship, these differing perceptions are often reduced to the convenient binary of debt and gratitude, control and subordination, and left unarticulated until family tension erupts.

The shifts in social relations are also evident at the communal level. Whereas traditionally, village projects, such as well digging, are embarked upon through collective planning and decision making, the prevalence of transnationally sponsored development has also been associated with the erosion of local participation, hence of local ownership of the process and the outcome. All too frequently, overseas sponsors not only remit the capital but also unilaterally determine the design and select the site for the construction. Distance is, therefore, measured not only in physical space but also in relational terms, in the impersonalism that, paradoxically, governs the very endeavours aimed at strengthening communal bonds.

With growing exchange and, paradoxically, the sobering of the initial euphoria, the challenges revealed by the expanding and deepening of transnational relations are not easily dismissed. Increase in travel to and from Southeast Asia and in the number and complexity of transnational family arrangements has intensified the growingly vocalized concern over the transmission of AIDS and the disparaging effects on the Cambodian family and society.

Because these concerns are mostly expressed by women in a context that remains entrenchedly patriarchal, they have yet to attain the necessary political decibel level. Nonetheless, they are symptomatic of the growing discomfort over the more destabilizing aspects of transnational dynamics. Though the ramifications of these transnational dynamics remain to be fully unveiled, these concerns nonetheless speak to the need to give theoretical emphasis not only to those who left, but also those who are left behind, on both sides of the geographical divide, in this transnational movement.

For the 1.8 generation $^{35}$ and the American-born, who are temporally disconnected from the immediacy of their parents' experiences, the "memory" of, and connection with, the homeland are, for the most part, nurtured and transmitted generationally within the family context. The reflection of this young volunteer who had returned as part of the Cambodian-American National Development Organization (CANDO), often referred to as the Cambodian Peace Corps, speaks to the fluidity between the "actual" and the "imagined":

... I have a lot of dreams, like the dream I had of working at Angkor Wat when I was in the United States. I even told my friends then of the magnificence of Angkor monuments without having been there. Except for what I had seen in picture books and from what my mom had told me, Angkor was just a childhood memory. But now, I live and work there. ${ }^{36}$

For many of the younger generation, it is the search for identity, through the reclaiming of a denied past, that compels the return. It is a way of connecting with their families, by sharing in the trauma that casts a pall even over those who did not live through those defining historical events. 


\section{Notes}

1. I have borrowed this technical term to connote one structural conduit that generates connections and reactions in multiple domains, often simultaneously.

2. Edward Said, quoted in Salman Rushdie, Imaginary Homelands (London: Granta Books, 1991), 180.

3. Wicker and Schoch, p. 17.

4. Said, in Yossi Shain, The Frontier of Loyalty (Wesleyan University Press, 1989), 10.

5. Akhil Gupta and James Ferguson, "Beyond Culture: Space, Identity and the Politics of Difference," Cultural Anthropology 7, no. 1 (1992): 18.

6. Rushdie, 12.

7. "Giving Up the Good Life to Return Home," Cambodia Times, July 15-21, 1996.

8. This term is commonly used in the literature on immigrants to refer to those who migrated when they were in their adolescence.

9. Personal interview, Cambodia, 1996.

10. John Sorenson, "Opposition, Exile and Identity: The Eritrean Case,” Journal of Refugee Studies 3, no. 4 (1990): 298.

11. US Census, 1990.

12. Renato Rosaldo, quoted in Roger Rouse, "Mexican Migration and the Social Spce of Postmodernism," Diaspora (Spring 1991): 17.

13. Linda Basch, Nina Glick Schiller, and Christina Szanton Blanc, Nations Unbound: Transnational Projects, Post-Colonial Predicaments and Deterritorialized Nation-States (Amsterdam: Gordon and Breach, 1991).

14. Nina Glick Schiller et al., "Transnationalism: A New Analytic Framework for Understanding Migration," in Towards a Transnational Perspective on Migration: Race, Class, Ethnicity and Nationalism Reconsidered, ed. Nina Glick Schiller, Linda Basch, and Cristina Szanton Blanc (New York: New York Academy of Sciences, 1992), 1-24.

15. Rouse, 15.

16. Anthony H. Richmond, "Reactive Migration: Sociological Perspectives on Refugee Movements," Journal of Refugee Studies 6, no. 11 (1993): 18.

17. Sorenson, 317.

18. James Clifford, "Diasporas," Cultural Anthropology 9, no. 3 (Summer 1994): 15.

19. "Back to Help Rebuild Cambodia," Cambodia Times, July 15-21, 1996.

20. Alejandro Portes, "Global Villagers: The Rise of Transnational Communities," American Prospect No. 25 (March-April 1996): 74.

21. Youk Chhang, "My Sister," Camnews, 1998, online: <http:// www.dccam.org/strick_rice.htm>.

22. "Back to Help Rebuild Cambodia," Cambodia Times, July 15-21, 1996.

23. Personal interview,.Washington, DC.

24. Portes, 74 .
25. Meena Alexander, in Ketu Katrak "South Asian American Writers: Geography and Memory," Amerasia Journal 22, no. 3 (1996): 121.

26. Ibid.

27. The effort to capture this market was reflected in a recent campaign in the Vietnamese-American community offering a retirement package at a riverside village in Cambodia where bucolic agrarian lifeways can be recaptured in sufficient proximity to Vietnam, but without the oppressiveness of a socialist state.

28. Um, interview with TK, Phnom-Penh, 1998.

29. Personal interview, Phnom-Penh, December 1996.

30. Ibid.

31. Personal interview, Oakland, March 1997.

32. Personal interview, Phnom-Penh, August 1997.

33. Soc.culture.cambodia, February 5 1997, online, <http://www. khmernews.com/thread-1.hgtml $>$.

34. Personal interview, Phnom-Penh, December 1996.

35. I have used this term to refer to those who migrate in their pre-adolescence in distinction to the 1.5 generation who come in their early teens.

36. Motherland (Washington, DC: CANDO Project, November $15,1994)$.

Khatharya Um is Associate Professor of Asian American Studies at the University of California, Berkeley. 